\title{
THE BYRONIC HERO MYTH RELOADED IN E. L. JAMES'S FIFTY SHADES OF GREYSERIES
}

\author{
Byronik Kahraman Mitinin E. L. James'in Grinin Elli Tonu Eserinde \\ Yeniden Yorumlanmasl
}

\section{Tatiana GOLBAN ${ }^{*}$ Mahri BABAGULYYEVA**}

\begin{abstract}
Assuming that the Byronic hero can be properly considered to be a literary myth and our contemporary popular culture keeps a constant interest in various ancient and modern myths by continuously rewriting and reshaping their thematic perspectives in its literary and not only products, the present study argues about and exemplifies these assumptions by focusing on E.L. James's famous novel trilogy Fifty Shades of Grey. This study draws on the Byronic hero as depicted in the nineteenth-century literature and attempts to reveal how this literary representation continues to fascinate the contemporary artists and readers and is reshaped unexpectedly in the contemporary romance. The postmodern romance fuses high and low culture and this study presents the ways in which the novelist wittily combines mythical and literary heritages with the striking images allowed by the romance mode in order to convey some stringent concerns of the present day society, such as childhood abuse, trauma and violence. The myth of the Byronic hero, as expressed in E.L. James's series, reveals a transformed version, a neo-Byronic protagonist who becomes adaptable to the norms of his community, is capable of moving beyond his trauma and is healed as a result of discovering his genuine love.
\end{abstract}

Keywords: Romance, literary myth, the Byronic hero, trauma, Fifty Shades of Grey

ÖZ: Byronik kahramanının tam anlamıyla bir edebî mit olarak kabul edilebileceğini ve çağdaş popüler kültürümüzün, çeşitli antik ve modern mitlere sürekli ilgi gösterip, bu ilgiyi sadece ürünlerinde sınırlı tutmayıp, edebiyatlarında da bu mitlerin tematik perspektiflerini, sürekli olarak yeniden yazdığını ve yeniden şekillendirdiğini varsayarak, bu çalışma E. L. James'in popüler hale gelmiş Grinin Elli Tonu roman üçlemesine odaklanır ve bu varsayımları tartışmayı ve örneklendirmeyi amaçlar. Bu çalışma, Byron kahramanını on dokuzuncu yüzyıl edebiyatında tasvir edildiği gibi ele alır ve bu edebi temsilin, çağdaş

* Prof. Dr., Tekirdağ Namık Kemal Üniversitesi, Fen-Edebiyat Fakültesi, İngiliz Dili ve Edebiyatı Bölümü, tgolban@nku.edu.tr, ORCID: 0000-0002-7860-0992

** Öğr. Gör., İstanbul Gelişim Üniversitesi, Yabanc1 Diller Yüksekokulu, mbabagulyyeva@gelisim.edu.tr, ORCID: 0000-0003-4693-1073

Geliş Tarihi / Received: 04.11.2020

Kabul Tarihi / Accepted: 10.06.2021

Yayın Tarihi / Published: 30.07.2021 
sanatçıları ve okuyucuları nasıl büyülemeye devam ettiğini ve çağdaş romansta beklenmedik bir formda nasıl şekillendiğini ortaya çıkarmaya çalışır. Post-modern romans, üst ve alt kültürleri birleştirir ve bu çalışmada, yazarın akılcı bir yöntemle, mitolojik ve edebi mirasların zenginliğini, günümüz toplumunun çocuk istismarı, travma ve şiddet gibi bazı endişelerini iletmek için, romans tarzının sağladığı bazı çarpıcı imgelerle birleştirdiğini görmekteyiz. E.L. James'in serisinde yansıtıldığı haliyle, Byron kahramanı miti değişime uğramakta, ve toplumun normlarına uyabilen, travmasını atlatabilen ve gerçek aşkın keşfiyle iyileşen yeni bir Byron kahramanı versiyonu ortaya çıkmaktadır.

Anahtar Kelimeler: Romans, edebi mit, Byron kahramanı, travma, Grinin Elli Tonu

\section{Introduction}

The recent literature and popular culture have expressed an extraordinary interest in myths, made visible through the numerous retellings of the Greek, Roman and Norse mythologiesin many contemporary novels, plays, movies, or TV series. It is already a well-known fact that each artist, in the process of re-imagining the myths, picks up those narratives which would bear a significance corresponding to his or her communal values, concerns, insecurities and anxieties.

This is also the case of E. L. James's Fifty Shades of Grey novel series. Viewed as worthless-housewife-porn or witty-sex-liberating endeavour, loved or loathed, discussed or criticized, it keeps stirring the interest of the reading audience. E.L. James created "an erotic romance novel that topped the New York Times best-seller list in 2012 and has become an uncanny worldwide success" (Illouz, 2014, 3-4). The Fifty Shades trilogy narrates the love affair between the inexperienced and insecure 21-year-old Anastasia Steel ("Ana") and Christian Grey, a 27-year-old self-created industrial magnate, whose practice of BDSM (bondage, discipline, sadism, and masochism) is connected to his dark past. The enormous popularity of the trilogy led E.L. James to write two more novels, Grey (2015) and Darker (2017), which, although narrate the same line of events, are depicted from Christian's perspective and both works proved to be similarly spectacular for the target audience. What looks intriguing in this case is that the twenty-first century has witnessed the flourishing of erotic literature, but none of its works are comparable to the degree of fascination that E.L. James's novels have produced. Moreover, her style of writing and the character typology has led to the creation of a trend of literature which is imitated by many contemporary novelists.

Despite the multiple attempts at finding an explanation for the immense appeal of E.L. James's novels, we believe that the fascination with this Fifty Shades series lies in the novelist's careful inclusion of some mythical 
scenarios, which combined with the wealth of a literary heritage, are is carefully woven into the text. Beyond the shocking erotic content, the novelist makes sure that the target audience recognizes these latently or patently placed mythical or literary scenarios, while wittily reimagining them and the most visible example, among many others, is the literary myth known as the Byronic hero.

\section{The Byronic Hero as a Literary Myth}

The term "literary myth" has always been met with extreme divergences by many literary scholars, partially this situation stemming from the difficulty of finding a consensual definition for the term "myth" and partially from the confusion regarding the use of the term "literary myth". The uncertainty concerning the terminology has brought many literary scholars to abandon the usage of the term "literary myth" altogether, whereas others assume the direction suggested byJean-Louis Backès (2010), which implies the reference to "provisional" definitions, used primarily in specific study contexts. These definitions are created in particular cases for the selected subject of analysis.

No matter how tedious is the path in the theoretical consideration of the term "literary myth", it is worth noting the contribution made by Philippe Sellier, who, in his "Qu'est-cequ'unmythelittéraire?" (1984), definines the literary myth by differentiating it from the ethno-religious myth. According to Sellier, the ethno-religious myth is anonymous and reveals the creation of something and consequently is regarded as true, whereas the literary myth originates in literature. The literature itself has the power to produce some stories which become myths in the process of their retelling, as in the case of Faust, Don Juan and others. When a myth emerges from literature, the determinant factor is played by the imagination of the artist, who assumes the liberty and flexibility while creating and presenting a symbolical situation which hasa significance for human condition and/or for societal existence. In the process of emergence of a literary myth, it preserves the "saturation with symbols" of the ethno-religious myth, but its initiatory and foundational characteristic is lost.

Another effort has been made by Pierre Brunel, who, in Companion to Literary Myths, Heroes and Archetypes (1992), stresses out the fact that literature represents a repository for the mythical content and, therefore, all myths are already "literary", since we have access to them only through their literary interpretations. In the Preface to the above mentioned book, Brunel 
suggests a very broad definition of the literary myth, which according to him, embraces "everything literature has transformed into myth" and refers not only to stories which are taken from the well-known mythologies, but also to certain literary works of famous authors which become myths as a result of the passage of time through their retelling, as well as to exceptional stories created by mythologized historical figures $(1992, \mathrm{xv})$.

The studies on literary myth assume a different turn with the contribution made by Gilbert Durand, who speaks of certain universal symbolic patterns which recur in literature as myths. Durand refers to some unique masterpieces whose texts develop into "a sacred language, which restores and establishes the primordial reality that creates a specific myth" and thus brings about original representations of new situations that are typical for the human condition as an expression of the profaned sacredness $(1998,167)$. Furthermore, the richness of meaning of a myth, together with its capacity to expand beyond the linearity of the signifier, would prompt that "signifier subsists as a symbol" (Durand, 1998: 343). The ability of the myth to fluctuate from the initial scenario "through losses, through mythemes originating in other myths" reveals once again its symbolic significance, which has validity in the era when the story is told (Durand, 1999: 303).

Following the above mentioned definitions, it can be assumed that the literary myth is primarily a story with a closed plot structure; it might originate in ancient myths, as in the case of Prometheus, Odysseus and Oedipus; it might also emerge from primordial myths, but as a result of artistic imagination, it creates a new story which exerts fascination and is representative for a community, such as the myth of Electra (Golban, 2004) or the myth of Medea (Golban, 2012) and is later retold in new literary versions; or it may stem directly from a literary work, as the product of an author's imagination, like Don Juan, Don Quixote and the Byronic hero, but when these "new stories" are created, they definitely rely on some symbolic situations or a "mythical kernel" (Durand, 1996: 190), on some recurring mythemes which strengthen the narrative scheme of the told story and at the same time, allow some space for variability in its scenario. To this could be added Marcin Klik's position, who claims that "[the] characteristic of literary myth perceived this way is not its aetiological or sacral function but its recurrence. Literary myth does not explain the secret of creation and does not refer to deity but only recurs in different variants in literary works" $(2015,96)$. 
In romantic literature, the literarization of the myth occurs primarily in a special type of drama known as "lyrical drama", the most famous texts being Shelley's Prometheus Unbound and Byron's Manfred and Cain. Drama, in particular, answers to Friedrich Schlegel's demand in Redeuber die Mythologie (1800) for a modern mythology which is "based on the revival and renewal of classical myth. The imaginative flight and the change of the classical myths as to transmit a new philosophy make recent critics discuss Romanticism as a myth-making movement" (Golban, 2013: 223).

The intention in this study is to present the Byronic hero as a literary myth, which originates in English Romantic period, as a product of Byron's creative imagination, as well as of his fascinating personality. It is a literary myth, since it produces a certain narrative schema, with a particular protagonist typology, which triggers some mental tendencies fixed in the collective unconsciousness, which would allow the experience of a reality, accompanied by certain reactions and emotions, or evoke certain universal patterns which are reflected in culture as a whole and become explored and represented by various writers of different periods in their works. It will not be an overstatement to claim that the Byronic hero was one of the most popular phenomena for the nineteenth-century literature and it produced an extremely fascinating figure with consequences which reach far beyond the nineteenth century Western literature.

As in the case of other literary myths, the Byronic hero does not stem only from the author's imagination, but relies on a number of symbolic patterns which are known from earlier literary representations, such as the Child of Nature, the Hero of Sensibility, the Gothic Villain or the Noble Outlaw (Thorslev, 1965). It also relies on some mythemes which could be recognizable from the mythic scenarios of Faust, Cain, Satan and Prometheus. Despite its multiple distinctive features, the Byronic hero exhibits some stable structural constants, depicted by Thorslev as "invariably courteous toward women, often loves music or poetry, has a strong sense of honor and carries about with him like the brand of Cain a deep sense of guilt. $\mathrm{He}$ is almost invariably sympathetic in spite of his "crimes", none of which involves unnecessary cruelty, as do the crimes of the Gothic villain" (1965: $8)$.

Golban admits certain variations to the stable nucleus of this literary myth, which are depicted as "hypostases of the Byronic hero", depending on the protagonists revealing both similarities and differences with regard to character representation strategies: 


\begin{abstract}
"Most of them reminiscent of a typical romantic persona, as well as of the author himself, the character Byron created is a handsome young person, of impressive aristocratic origin, rejecting and being rejected by his own class; proud and egocentric; a misfit and outcast in relation to any social environment, inadaptable and solitary, concerned with separating himself from humanity and seeking solitude, knowledge and worlds of escapism created or re-created by his own imaginative resources; and last but not least, a rebel and radical by the English standards of his day" (2018: 203).
\end{abstract}

Although the Byronic hero seems to be much encompassing, the mythical scenario is recognized and, through the intervention of variable elements which are typical to any myth, it can be distinguished as following:

"Child Harold displays at first rebelliousness and then escapism; Manfred (...) wishes escapism, or rather aims to escape the escapism, since isolation and seclusion, suggesting accomplished escapism, bring neither happiness nor the desired oblivion. (...) Cain (...) wondering throughout the worlds, is a romantic rebel; his rebelliousness, however, has little to do with any social background or the poet's concern with social, moral and normative aspects of existence. On the contrary, Don Juan is expressed as a rebel in the milieu" (Golban, 2018: 203).

Although the hypostases can be numerous, the literary myth, known as the Byronic hero, persists through its recurrence in various literary works. The specific narrative schema and the particular protagonist type of this myth become identifiable already in the nineteenth-century Western literature, certainly in the characterssuch as "the Bronte sisters' Heathcliff and Rochester", "Pushkin moulded his Eugene Onegin in Childe Harold's image" (Thorslev, 1965: 3), some features of the Byronic hero are easily recognizable in Thomas Hardy'sAlecD'Urbervilles, in Oscar Wilde's protagonist Dorian Gray or even in James Joyce's Stephen Dedalus. Some other examples of the Byronic heroes could be considered Ernest Hemingway's Jake Barnes, Scott Fitzgerald's Jay Gatsby, all these characters being marked by a dark sensibility, cynicism, arrogance, high intelligence and a refusal to conform to the outright authority.

A typical Byronic hero is represented in literature as an enigmatic antihero, a tragic soul who acts without a clearly stated code of ethics and often appears quite selfish. Whether accepted as a literary myth or not by the scholars, the Byronic hero becomes a timeless figure which is recurrent in world literature, cinema and other artistic forms. Particularly, this mysterious hero/villain emerges in various hypostasis in pop culture, to name just Edward Cullen, the protagonist of the Twilight Saga, Serverus Snape from Harry Potter Series and Christian Grey from Fifty Shades Series. These dark and brooding characters who appear unbearably seductive, emerge from 
within the structures of the Byronic myth, but each of them arises in different narrative versions which provide new meanings for the culture and context in which they are produced.

\section{Christian Grey as a Neo-Byronic Hero}

The present day popular culture surely reveals an extreme interest in the Byronic hero myth, but it comes as a complete surprise to see the representation of this mythical scenario in a product which has frequently been labelled as fan fiction or erotic romance. Undeniably James's novel series Fifty Shades has been initially written in order to explore the boundaries of erotica genre and much of the popularity of this series is due to the explicit "vanilla" or "kinky" sexual scenes it depicts. However, it might be argued that James's series transcends the boundaries of a common erotic romance, reflected through the frequent insertion into the novels of multiple mythic elements, quotes from various classical texts, and through the main thematic concerns which lie at the heart of herworks, precisely the trauma experienced by an individual at a certain moment in his life and the ways of coping with or healing from the traumatic experience.

It is acknowledged that a certain myth arises whenever it corresponds to some communal anxieties; it is used by an artist or author in order to represent a crisis which dominates the historical moment in which the myth is depicted. As myth is capable of accommodating within its narrative the perpetually shifting conditions, the Byronic myth emerges in order to reveal a code of signification which reflects a shift in values related to trauma, abuse, victimization, pain and love. In other words, the mythical scenario of the Byronic hero exposes a crisis in contemporary communal existence, like the traumatic experience of childhood abuse and it allows questioning the possibility of love to heal the damaged individual.

Diane Elam claims that in romance, "the division between high and low culture [...] becomes blurred" (1992: 1), there is definitely a "persistence of excess" (1992: 2), but most noteworthy is the fact that romance "exists as a contradictory term from the start" (1992: 5). Susana Onega and Jean-Michel Ganteau speak of "the malleability of the mode or, more generally, the sense of a collaborating, all-encompassing essence of romance" (2012: 3), whereas Pierre Vitoux views romance primarily as a reactive mode, since it exists in simultaneous reaction and relation to the other mythoi detected by Frye (2007: 392).

Following the direction indicated by the above mentioned scholars, it could be noticed that James's promotes the subversion of the generic modes 
and leaves room for the openness of expression of the conventions and concerns which often transcend the genre of romance. Thus, the mythical scenario of the Byronic hero allows the novelist to blur the limits between genres, by reaching out for the conventions of traumatic literature, some elements of epistolary novel, of Bildungsroman as well as of dark romance, attaining a fusion that increases the tension in the narrative, which eventually delivers the archetypal hero's quest from inner conflict to self-realization, all made possible only after the encounter of the true love.

The romance frame ispreserved throughout all the novels of the series, making itself visible initially via the depiction of Ana's admiration of Christian's physical appearance, who is presented as very attractive and tall, "with unruly dark copper-colored hair and intense, bright gray eyes" (FSOG, 2012: 7). Christian's physical description bears some reminiscence with the Gothic villain, who is dark and strikingly handsome, manly, with an athletic physique, with the most noticeable grey eyes which fascinate Anastasia from the beginning of their endeavor. The novelist makes sure that the readers follow Ana in her admiration of this young man, by making frequent remarks about Ana's perception of Christian, while stating that "[he]'s not merely good-looking - he's the epitome of male beauty, breathtaking" (FSOG, 2012: 25), or "[he] is beyond beautiful. He is jaw-droppingly handsome" (FSOG, 2012: 311). Christian Grey resembles a Byronic hero especially by his intelligence and passion in everything he does; his exceptionality is evident in being accepted to Harvard just to prove that he is capable, in his ability to fly a plane, sail a boat, impressively play piano, or by the fact that at the age of 27 he is already the CEO of Grey Enterprises Holdings, Inc., a very rich, self-made man who seems to dominate the world.

James, while creating her protagonist Christian Grey, takes into consideration "the politics and representation of masculinity in the popular romance novel" (Allan, 2016: 27), which conforms to the standard expectations of masculinity as strong and powerful. However, as romance encourages extravagance, excess and adventure, we discover the novelist's depiction of the protagonist as exceeding all norms and expectations, alludingeven more to the exceptionality of the Byronic hero. It is not only the sense of power that Christian emanates, as he employs over forty thousand people by Grey Enterprises Holdings, but the control he exercises is impressive. During the interview that Anastasia conducts, he explains:

“I don't have a philosophy as such. Maybe a guiding principle - Carnegie's 'A man who acquires the ability to take full possession of his own mind may take 
possession of anything else to which he is justly entitled.' I'm very singular, driven. I like control - of myself and those around me" (FSOG, 2012: 11).

The last statement alludes to the Byronic spirit and it becomes obvious that regardless of power and control that Christian exudes over so many people, he does not enjoy the company of men. The places Christian inhabits, his office or his penthouse, both suggest an ivory tower, high, aloof, enormous spaces, which resemble mostly the castles of the Byronic heroes, who live isolated and lonely, mostly due to their feeling of inadequacy. Christian's office is cold, clean and clinical, whereas his penthouse, which is placed at the top floor of a skyscraper, with its glass walls that overlook Seattle, seems to disclose to infinity. These spaces create a mysterious atmosphere, "since such places are normally forbidden to ordinary mortals, they do work in an escapist direction and contribute towards constructing the enchanted kingdom of dreams in fantasy" (Goşa, 2014: 67). The escapist feeling is also created by the emphasis the protagonist lays on art, both in his office and house, as in the living room of Christian's apartment, there is a full-sized black grand piano he often plays, the walls of his house display pieces of art of all shapes and sizes, a fact that leads Anastasia to think of it as a gallery rather than a home, whereas on a wall in his office there is a mosaic of small, exquisite paintings which depict mundane and forgotten objects. Since art is transcendent and dominating, it holds the control over the worshiping subjects; therefore, Christian's desire to identify with it does not come as a surprise, as it truly corresponds to his nature.

The highly symbolic motif of crossing of a threshold is enacted for the first time when Anastasia enters Christian's office and literally stumbling at the threshold, she falls. Anastasia's fall gains an emblematic significance, as due to this fall Christian starts paying attention to her; Ana's beauty, combined with her embarrassment and frequent blushing, makes him think of her as a natural submissive. But this fall gradually gains connotations beyond the immediate visibility. First of all, Anastasia trips over her own feet and falls into Christian's office, entering a space she has not been yet; symbolically, she crosses over into a terra incognita, a mysterious territory she does not know and whatever she experiences from this moment assumes the significance of the mythical exposure to knowledge. It is interesting that after looking at the paintings on the wall of Grey's office and Christian introduces her to the works of Trouton, a local artist, Ana exclaims the essence of art, but, unwittingly also utters her condition from now on, which is "[r]aising the ordinary to extraordinary" (FSOG, 2012: 8) and this is exactly what Christian wants to do out of their relationship. 
Cedric Hentschel describes the Byronic Hero as "a tripartite individual", claiming that "he is the type of satanic, sadistic dandy" and "insofar as he is satanic, he is a descendant of Prometheus Lucifer, meaning that he is a sadist, he stands in the shadow of the 'divine Marquis'; as a dandy, he manifests fastidious exhibitionism" (2016: 8-9). Hentschel's depiction of the Byronic hero leads to our second assumption related to the moment of Ana's fall, as it gains an extraordinary saturation with Edenic symbols. The novelist is extremely witty when she suggests a very ambiguous fall out of Eden, since Anastasia would be eventually seduced by Christian, this satanic dandy, who tries to ensnare and corrupt the innocent Ana into a BDSM relationship; or the ambiguity goes further, since letting herself seduced by Christian, the pun intended, she falls into a paradisiacal state of bliss.

The motif of knowledge has also been reworked in a very original manner by-James. Initially, Christian embodies the trickster, bearing something of the satanic tempter who tries to allure and ensnare the clueless Ana in the stalking episode at Clayton's. He manipulates her into believing that their meeting happens by chance, at her working place, using thisopportunity to charm Ana with his presence. Temptation through knowledge is powerfully conveyed at the beginning of the trilogy and as Satan tempts Eve with the fruit of knowledge, being followed by the corruption of humankind, Christian tries to seduce Ana, by stirring her desire to reach and know him, observing that "[like] Eve, you are so quick to eat from the tree of knowledge" (FSOG, 2012: 74).

Since nothing is ordinary when it comes to Christian Grey, the relationship he envisages for the two of them is extraordinary as well, as Christian comes with a Contract for a Dominant - Submissive relationship, which is supposed to be signed and respected by the two of them. Similar to the satanic episode, the consequence of Ana's gaining of knowledge should come at an enormous price. Ana is shocked and bewildered when she thinks that here "he comes with a bloody contract, a flogger and a whole world of issues" (FSOG, 2012: 176). It is interesting to observe that this "bloody contract" gains a more Faustian quality, as it reminds of the Luciferian contract with Faustus, sought for the sake of knowledge, signed in blood, as a result of which Faustus loses his soul and body. Allusions to Ana's virginal blood being spilled as a result of her desire "to know" Christian are strongly rendered in the novel. But, the reader should not be misled by this mythical suggestion of loss. James proves to be extremely creative and playful with the mythical allusions and as the relationship between Christian and Ana 
progresses, the boundaries between the tempter and the temptress are blurred. Ana, wittily delays the signing of the contract and as a result of her gradual exposure to knowledge, is the one who becomes Faustian, because she tempts Christian with her desire for "More". Ironically, the innocent Anastasia manages to ensnare Christian into wishing for "More" and from a man who claims that "there are people who'd say I don't have a heart" (FSOG, 2012: 11), his "More" gradually transcends the banality of a simple desire for someone's body, gaining instead an aura of desire for spiritual accomplishment and wholeness.

However, Christian Grey, by no means, should be confused with a ruthless, demoniac villain. Although he is extremely attracted to Anastasia, he initially tries to fight his own temptation for this "innocent" girl. When they meet for a coffee after the photo shoot, he understands that she is too young and pure for him, and though he is aware that Ana is extremely fascinated by him, he is very determined when he says: "Anastasia, you should steer clear of me. I'm not the man for you" (FSOG, 2012: 49). He is also aware that he has hurt Ana enormously by his rejection and in a Byronic hero's manner, he tries to make a kind gesture with a generous present of Thomas Hardy's first edition from 1891 of Tess of the D'Urbervilles. Beside the extremely expensive three volumes of Ana's favourite novel, Christian adds a handwritten message, a very thoughtful quote from Tess which functions as a warning against himself: "Why didn't you tell me there was danger? Why didn't you warn me? Ladies know what to guard against, because they read novels that tell them of those tricks..." (Grey, 2015: 47).

Christian, almost like Byron's Manfred, struggles against his own desire for Ana when he tries to warn her off, thinking that his own "depravity" will drive her into his darkness, threatening to destroy her completely. But, the more he tries to break off his attraction to Ana, the more he is driven like an adamant to her. The intensity of their mutual attraction definitely keeps the framework of romance intact, nevertheless the novelist makes sure that the protagonists, as they navigate into their sexual relationship, leave no ground for abuse. Christian, the seducer, no matter how much he bewilders Anastasia by his "sexpertise", always asks for her consent and trust. Again, the malleability of romance mode is recognized, as the novelist tries to insert a message which collaborates with today's sexual climate and as Francesca Tripodi suggests, it delivers "affirmative consent policies as a way of combating the problem of sexual assault", making sure that sexual engagement should be "knowing and voluntary" (2017: 103). 
One can also recognise a Promethean quality in Christian Grey, who develops a personal vision of goodness; although seeking pleasure through pain, he is extremely generous in various charities and donations. Speaking of the Byronic hero, Atara Stein urges that he has "ambition, aspiration, aggressive individualism and 'Promethean spark'... he is an unattainable ideal, a hero who inspires awe" (2004: 1-2). Christian carries these features and he is awe inspiring when he holds his speech at Ana's graduation ceremony at WSUV, his purpose being stated impressively:

\footnotetext{
"Our aim is to develop viable and ecologically sustainable methods of farming for third world countries; our ultimate goal is to help eradicate hunger and poverty across the globe. Over a billion people, mainly in Sub-Saharan Africa, South Asia, and Latin America, live in abject poverty. Agricultural dysfunction is rife within these parts of the world and the result is ecological and social destruction. I have known what it's like to be profoundly hungry. This is a very personal journey for me..." (FSOG, 2012: 237).
}

Anastasia, who is dazzled by Christian, tries to resist the temptation of his unorthodox proposal since she understands that he is not a flawless man. However, when he holds the speech at the graduation, she has a glimpse into his mystery. She becomes aware that Christian's personality emerged as a result of a horrible abuse that had taken place in his early childhood, before the Greys adopted him at the age of four. The thought of a hungry and grayeyed toddler creates a sense of outrage in Ana, which leads her to view him from now on from a different perspective: "Poor, fucked-up, kinky, philanthropic Christian - though I'm sure he wouldn't see himself this way and would repel any thoughts of sympathy or pity" (FSOG, 2012: 237).

Christian Grey, like a typical Byronic hero, is a solitary outcast and his bad temper, overbearing and cold, emotionless self develop as a result of the childhood abuse by "one of the crack whore's pimps" (FSD, 2012: 37), who regularly burned the child's body with cigarettes, whereas his birth mother, being constantly on drugs, turned a blind eye to such cruelty. The neglected and harmed child developed an algolagniac state, since he cannot bear being touched. His statement "[t]ouching is a hard limit for me, Anastasia" (FSD, 2012: 37) preserves his torment and exposes his vulnerability which emerges as a result of the unspeakable horror he has lived through at a very early age. Experiencing a perversion of love or the lack of it from a careless mother, the constant maltreatment by her pimp and forced to witness his mother's dead body for four days, alone and hungry, deeply affect Christian. Although adopted by the loving and dedicated Greys at the age of four, he cannot overcome this trauma. Considering himself unworthy of the affectionate 
Greys, Christian becomes self-destructive; the lack of maternal love takes its toll and he becomes unable to acknowledge the perversion of love which he is led into by Elena Lincoln, aka Mrs. Robinson, the adult woman who seduces the 15-year-old Christian and initiates him into the secrets of BDSM.

The presence of trauma in this narrative makes E.L. Jamesto stretch out the conventions of romance by incorporating the modal strategies of traumatic literature and developing some trauma-related themes. Ángeles de la Concha claims that " $[\mathrm{t}] \mathrm{rauma}$ and romance usually make a poignant coupling suggesting the intimacy of love and pain, the density of a luminal space harbouring life and bereavement, presence and absence, the real and the spectral" (2012: 129).

Trauma blends well with the mythical scenario of the Byronic hero, who is likewise haunted by the nightmarish and ghostly figures of his past. James inflames the mysticism of this scenario by weaving into her narrative the features typical of Gothic fiction; consequently, it conveys the extravagance and excess of the morbid in the depiction of Christian's half-remembered, but repeated in the present recollections:

\footnotetext{
"I have vague memories of the place: drunks, hobos and crack-heads shouting at us on the streets; the seedy dive we called home; and a young, broken woman, the crack whore I called Mommy, staring into space while she sat in a drab, grimy room filled with stale air and dust motes. And him" (Grey, 2015: 361).
}

Christian Grey, like the Byronic hero, is a transgressed man with a tragic and mysterious past that fueled his revolt against society and its norms; it can be said that his adherence to BDSM expresses simultaneously his desire for rebelliousness and escapism. Thinking that he can never be loved and needing to deliver his anger and fury, he embraces sadism and masochism as a way of coping until he finds gratification in it.

The tormented but very charming Christian Grey, with his mercurial shifts of mood, is definitely a man of extremes. He somehow resembles Manfred, in that he is extremely keen on his individual freedom and privacy of his own principles; in his rebelliousness he establishes his own set of rules and his own code of ethics and he doesn't bow to conventional decorum. At the same time, Christian is a self-reliant person, who knows what he is doing very well; he is a very determined "man of many talents", hence is his arrogance. But although he has achieved so much in his short life, he is still incapable of understanding his worth beyond his business life. He seems to be trapped in a self-created and self-deceptive reality, meant to help him 
tolerate some images of the self which he could otherwise simply not abide. He finds an outlet in multiple activities, like soaring, flying, working-out, sailing, piano, BDSM, business, all these occupations requiring control, which is necessary to him in order to cope with the conflict of viewing himself as a monster. Self-absorbed, even obsessed with this conflict, he exclaims: "No one can love a monster, no matter how compassionate they are" (Darker, 2017: 46). Christian's emotional insecurity and vulnerability reach a tone of confession when he declares: "I'm nothing, Anastasia". I'm a lost boy, standing before you. Unloved. Abandoned by the one person who was supposed to protect me, because I'm a monster. ... "I'm a husk of a man. I don't have a heart" (Darker, 2017: 218).

The monster represented here should not be mistaken to a beast seeking sadistic acts of violence as an actegratut, sincehe is cast mostly as a Byronic figure who struggles to embrace his vulnerability, instinctivelybeing in quest of understanding, compassion and unconditional love. It is through confession, love and care whichhe experiences with Anastasia thatthey manage to foster a space, where Christian Grey becomes gradually able to admit his vulnerability and integrate his fractured emotional states in a meaningful whole. This love presumably should save the monster from his insularity, dismal and above all, loneliness.

Romance encourages the possibility of a resolution of trauma and welcomes the ecstatic tendencies of a happy ending; therefore, it boosts the representation of a "healing phase" that helps to "evoke the move beyond trauma" (Onega and Ganteau, 2012: 9). But this healing phase should not be understood as a kind of fairy tale miracle which comes up as a result of the waving of a magic wand. On the contrary, the novelist reveals the titanic inner struggle of the protagonist during this process of his search for knowledge about himself, which assumes a quality of a quest for his lost innocent self, from whom he has grown utterly estranged. In an absolutely Gothic manner, visible especially in the novels told from Christian's perspective, Grey (2015) and Darker (2017), the protagonist is depicted with self-doubt and self-loath, who projects himself as a monster with a dark and twisted soul, capable of feeling only in relation to his childhood memories of hunger, violence, abuse, abandonment and death. This is the reason why he has embraced the Dominant-Submissive relationships, enjoyed mostly in the playroom, which is called by Anastasia "The Red Room of Pain", as these kind of affairs are completely devoid of any emotions and as Christian himself mentions, this is the only way he knows. 
The motif of knowledge is reworked again, but, unlike the initial symbolism which suggests the temptation through knowledge which has the disastrous effect of falling into infernal darkness, it gradually starts to gain the significance of healing, a long journey in which Christian is helped and guided by Ana. Although he warns Anastasia from the very beginning that he is not "boyfriend material" (Grey, 2015: 144), he cannot do "hearts and flowers" and "romance" (Grey, 2015: 229), she adamantly wishes for "More", telling him: "You know all the wrong things" (Grey, 2015: 229). Sandra L. Bloom claims that some realities are totally unbearable, so "there is a high price to pay for self-awareness" (2010, 201-202). She refers to the issue of emotional contagion, implying that our emotions are frequently determined by the interactions one has with the others, which may have a positive, catharctic outcome, but can also disclose the individual to extreme vulnerability. Therefore, as a result of the interaction Christian has with Anastasia, one observes how Christian starts experiencing the emotional awakening and despite his overbearing masculinity, power and control, he reveals his need for healing, letting go off the monster he sees within himself and allowing his softness to disclose care and love. He acknowledges the recognition of his emotions when he says: "It's becoming familiar but I don't want to put a name to the feeling. It's too new. Too scary.... Usually, I try to avoid eye contact with the asshole in the mirror, but today he looks happier" (Darker, 2017: 150).

Ana embarks on a self-imposed mission to guide Christian through this difficult process and though she initially lacks experience and knowledge and is totally dominated by Christian's charismatic persona, she seems to absorb her wisdom from the symbolical unknown and the darkness into which she descends with him, struggling with her personal insecurities, Christian's unbearable image of himself and his sadistic inclination to inflict pain, which has developed as a result of his childhood trauma. The significance of Anastasia's name cannot be ignored; originating in the Greek word anástasis, it means "resurrection", a name with powerful biblical implications, especially in the case of an extraordinary young woman, who makes Christian realise his estranged self, driven away by the perversion of love and denial of feelings which he has experienced. It is not in vain that Christian calls Ana his "guiding light", while explaining that "I'm her lost boy, now found" (Darker, 2017: 526) or, "She's driving the darkness out and I'm drinking in her light" (Darker, 2017: 144). 
The religious symbolism implied by the novelist cannot gounnoticed, especially when the name of the novel's protagonist is Christian, respectively the follower of Christ, and the symbiosis created by E.L. James in relation to the Edenic parable of the temptation is amazing. Initially referring to Satan's allure of Eve with the apple from the tree knowledge, in the "healing phase" of the protagonist, the parable loses completely its negative connotations, the novelist conferring to the mythical scenario new significances. It is worth noting Christian's flashbacks from his childhood after being adopted, which represent happy memories from his Grandpa Theo Trevelyan's orchard, in which the old man teaches Christian how to cultivate the apple trees; significantly, these flashbacks are enlivened after the relationship with Anastasia has begun. E.L. James's choice of the name "Theo", which means "god" in Greek, is not random either. The orchard experience in the company of grandfather Theo creates some intertextual relations with the "Prologue in Heaven" from Goethe's Faustus, where the Lord strikes a bet with Mephistopheles concerning the success or failure of the human being vis-à-vis temptation, Lord stressing out that human should not be viewed as a finished product, but rather, using the metaphor of a tree, which takes time to deliver its fruit, reveals human as perpetually in a process of growth, therefore capable of change and development.

This symbolism of growth and change, suggested by the tree metaphor, is extremely important in relation to the capacity of the romance to depict a happy moment beyond trauma. The Byronic hero, generally speaking, is a self-destructive individual, incapable of moving beyond his traumatic experiences, remaining enmeshed in his overbearing superiority and never finding capacity to cross over his sense of inadequacy, ending up alone and haunted. Still, as in the case of Manfred, he struggles against his own ambiguity, growing aware that love transcends the dualism and the escapism of existence, whereas in Cain's case, he eventually abandons his demoniac side, conferring true value to love, understanding that love is the only true human value, as it encompasses all other values and therefore, it transcends rebelliousness. Nevertheless, both of them continue to be inadaptable rebels, remaining in the fostered dualism of existence, still seeking escapism.

What makes Christian Grey a neo-Byronic hero, is that being guided by the newly discovered unconditional love which he experiences with Anastasia, he reveals a possibility of resolution of trauma, his healing being boosted through the depiction of the biblical episode. The revelation of the possible happiness is attained by the creation of a paradisiacal space, which 
comes as a result of Christian's quest for his lost innocent self, discovered by him in the childhood experience in the apple garden with grandpa Theo, but attained fully as a result of his mature attempt to integrate his fractured emotional experiences into a wholeness, while guided by Ana. Allured by Anastasia scent of apples, Christian seeks his happy space, questioning himself: "Where is my happy place? My childhood in the orchard. Now my happy place is with Ana" (Darker, 2017: 292). In the same line, Christian envisages Anastasia, saying that "[she] tastes of heaven and home and fall and Ana" (Darker, 2015: 476), the fall this time does not represent corruption; on the contrary, it symbolizes the lover's fall into blissful love.

It is obvious from the beginning of the narrative that Christian Grey is a social outcast, just like a Byronic hero, who dwells in a self-created dualism of existence. He is not estranged by his society, but he tries to escape it as a result of his own choices, creating a liminal space for himself in all his activities, provided by art, music, flying, soaring, sailing, etc., whereas his choice of BDSM might be understood both as an escapist act, as well as a rebellious one, as he refuses to conform to the norms of the "normal" imposed by his society. It becomes a titanic effort to drag Christian out of the escapism provided by his BDSM relations, and it becomes possible along the mutual journey Christian assumes with Anastasia, as she tries to persuade him that he is worthy of love and care. He was already a reformer, much like Prometheus, visible in his incessant need to support the development of the alternative methods for food production and also in his persistence in encouraging solar based technology, which should become accessible to the less privileged people. But along his way, due to the love he discovers, he proves capable of reforming himself as well.

The radical change begins when he loses Anastasia, after she convinces him to show her how far he can go into his darkness in "The Red Room of Pain", shocking her because of the delight he finds in pain and also because she is afraid he will never be able to love her. The loneliness which Christian experiences after Ana leaves him is not the one he enjoyed prior to meeting her. It a kind of solitude which creates an enormous emptiness and excruciating pain, but this form of pain he does not enjoy either, for he acknowledges that he cannot bear hurting Ana. The pain of losing Anastasia creates an epiphanic moment, which makes him reconsider his attitude in life and pushes him to accept some norms of society, as he wishes Anastasia to become his girlfriend and start an "ordinary" relationship, instead of the Dominant-Submissive one, initially suggested by Christian, by which 
estranging himself completely from BDSM. Believing that he is incapable of feeling, he is totally shocked at the discovery of his love, emotion which makes him feel vulnerable and insecure, since it shatters the boundaries of his escapist mode of existence; but no matter how frightened he feels by the unknown, he is willing to embrace the challenge of a relationship. His inner doubts are driven away, as he meditates:

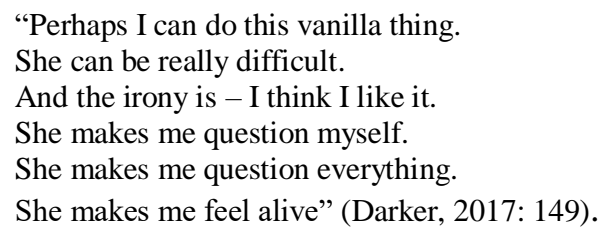

As it becomes clear from the quote above, Christian is both scared and fascinated by the new challenges brought into his life by this relationship with Ana. She makes him question his perception of the world and, above all, the way he sees himself and the way he is seen by others, both moments crucial in his healing process. Following the flight accident in which Christian almost lost his life, he returns home to acknowledge his family's genuine concern for him, and in their worry he discovers the significance of unconditional love. As he reflects, "[t]hey care. They fucking care. They were all worried about me. Family first" (Darker, 2017: 473).

His newly gained capability of love and the awareness that people can genuinely love him back become decisive factors in the next stage of his change. Forced to confess to Anastasia his darkest secret of being a sadist after the trial through which they passed with his ex-submissive Leila, Christian discovers that the knowledge of truth about him does not estrange Ana from him, nor does it make her feel disgusted of him, as this was Christian's greatest fear; instead, she once again admits to her unconditional love. Moreover, following this confession, they learn from Doctor Flynn that sadism is not a psychiatric condition, but a choice, a lifestyle. The knowledge of Anastasia's unconditional love and care makes Christian embraces another social norm, that of marriage. His passage through this phase transforms Christian enormously, becoming a new Christian Grey who quits being an inadaptable rebel and embraces the possibility of finding happiness not in his escapism, but in marriage. As he admits to himself, "Yes. She makes me happy". "It's a new feeling. I've never described myself in those terms" (Darker, 2017: 164). 
The final phase of Christian's transformation is represented by the experience of Anastasia's unexpected pregnancy, a fact that shocks both of them, but especially Christian, due to his difficulty of accepting his worth. The possibility of becoming a father shatters the newly gained sense of security he discovers in love and makes him extremely vulnerable again, as he is afraid that he might resemble his birth parents, who abandoned and mistreated him as a child. However, the fear of losing Ana as a result of threats and attack of her former boss proves to be greater than the fear of failing as a father. Once again, Ana's encouragement and support make him gain confidence that he will overcome his childhood trauma and he embraces yet another societal norm, that of being a father of a son, to be named, not surprisingly, Theodore.

\section{Conclusion}

James's Fifty Shades series explores the mythical scenario of the Byronic hero, as she finds within the space of this myth an opportunity to reveal the stringent concerns and fears of the contemporary age. Christian Grey's journey from traumatic childhood experiences to trust and love of "hearts and flowers" delivers the communal fears concerning the childhood abuse, neglect, sexual molestation, while simultaneously allowing the possibility of seeing beyond the traumatic events and, therefore, strengthening the possibility of healing, extremely important for the shattered communal faith in values and norms. Christian Grey possesses some features inherent to the Byronic hero, having in common with his predecessors, such as the Hero of Sensibility, the capacity of feeling melancholy and love; like the Child of Nature, he displays aggression; like the Gothic Villain, he is exceptionally beautiful and destructive, while embodying concomitantly some other features which fit Satan, Prometheus, Faust and Cain.

However, no matter how much he resembles the Byronic hero, it can be said that Christian Grey represents a different hypostasis of the Byronic hero, or rather a neo-Byronic hero, since E.L. James's character is a rebel, by dropping from Harvard as a result of his refusal to conform to the norms and expectations of his society; he is positioned in the dualism of existence, between BDSM and normative/vanilla relationship; he seeks escapism, as a coping mechanism for his traumatic past; but unlike all the Byronic heroes who remain inadaptable, Christian Grey, with his inherent grayishness, manages to go beyond his traumatic experiences and become an adaptable rebel, who abandons his previous form of escapism and finds a new necessary escape in his love with Anastasia. Although he adapts to the 
normative monogamous marriage, embraces parenthood and "vanilla" sexual relation, the love he discovers with Anastasia yet allows him to remain sexually adventurous in their bedroom. One could say that the novelist presents this obvious transformation of the Byronic hero, since she delivers an example of how human capacity to love and care makes a difference and it is important to see the success and accomplishment of an individual at the private level of his existence, who, regardless of his exceptionality, is a tormented person capable to find salvation in love.

\section{REFERENCES}

ALLAN, Jonathan A. (2016), "The Purity of his Maleness", In Journal of Men's Studies, SAGE Publications, 24.I, 24-41.

BACKÈS, Jean-Louis (2010), Le Mythe dans les littératures d'Europe, Cerf éditions, coll. "Cerf Littérature", Paris.

BLOOM, Sandra L. (2010), "Bridging the Black Hole of Trauma", In Psychother Politics. Int., Wiley Online Library, 8.3, 198-212.

BRUNEL, Pierre, ed. (1992), Companion to Literary Myths, Heroes and Archetypes, Routledge: London.

CONCHA, Ángeles de la. (2012), "Strangers to Ourselves: Story-telling and the Quest for the Self", Edited by Onega Susana and Ganteau Jean-Michel, In Trauma and Romance in Contemporary British Literature, Taylor\&Francis Group, 127-143.

DURAND, Gilbert (1996), Introduction à la mythodologie Mythes et societes, Albin Michel, Paris.

DURAND, Gilbert (1998), Figurimiticeşichipuri ale operei, Bucureşti: Nemira.

DURAND, Gilbert (1999), The Anthropological Structures of the Imaginary. Translated by Margaret Sankey and Judith Hatten, Bumbana Publications, Brisbane.

ELAM, Diane (1992), Romancing the Postmodern, London and New York: Routledge.

GOLBAN, Petru (2013), The Foundations of English Literary Criticism: From Philip Sidney to Henry James, Lewiston: The Edwin Mellen Press, Ltd.

GOLBAN, Petru (2018), A History of Bildungsroman: From Ancient Beginnings to Romanticism, Newcastle upon Tyne: Cambridge Scholars Publishing.

GOLBAN, Tatiana (2012), "Redirecting Thematic Perspectives: Euripides' Version of Medea Myth as the Rise of a Literary Myth", In The Annals of Ovidius 
THE BYRONIC HERO MYTH RELOADED IN E. L. JAMES'S

FIFTY SHADES OF GREYSERIES

University of Constanta - the Philology Series, Constanta Romania XXIV.2, 70-78.

GOLBAN, Tatiana (2004), “Ancient and Modern Hypostases of Electra Myth”, In Dumlupinar Universitesi Sosyal Bilimler Dergisi, 11, 41-52.

GOŞA, Codruța (2014), "From Fantastic Twilight to Fifty Shades Fanfiction: Not Another Cinderella Story", Edited by Dana Percec, In Reading the Fantastic Imagination: The Avatars of a Literary Genre, Cambridge Scholars Publisher, 57-76.

HENTSCHEL, Cedric (2016), The Byronic Teuton: Aspects of German Pessimism 1800-1933, New York: Routledge.

ILlOUZ, Eva (2014), Hard-core Romance: Fifty Shades of Grey, Best-sellers and Society, Chicago, IL: University of Chicago Press.

JAMES, E.L. (2012), Fifty Shades of Grey, London: Arrow Books.

JAMES, E.L. (2012), Fifty Shades Darker, London: Arrow Books.

JAMES, E.L. (2012), Fifty Shades Freed, London: Arrow Books.

JAMES, E.L. (2015), Grey, London: Arrow Books.

JAMES, E.L. (2017), Darker, London: Arrow Books.

KLIK, Marcin (2015), "The Crisis of the Notion of Literary Myth in French Literary Studies", Edited by José Manuel Losada and Antonella Lipscomb, In Myth in Crisis: The Crisis of Myth., Cambridge Scholars Publishing, 9199.

ONEGA, Susana and GANTEAU, Jean-Michel (2012), "Traumatic Realism and Romance in Contemporary British Narrative", Edited by Susana Onega and Jean-Michel Ganteau, In Trauma and Romance in Contemporary British Literature, Taylor\&Francis Group, 1-14.

SELLIER, Philippe (1984), “Qu'est-cequ'unmythelittéraire?”, In Littérature, 55, 112-126. La farcissure. Intertextualités au XVIe siècle.

STEIN, Atara (2004), The Byronic Hero in Film, Fiction and Television, Carbondale: Southern Illinois University Press.

THORSLEV, Peter L. (1965), The Byronic Hero: Types and Prototypes, University of Minnesota Press.

TRIPODI, Francesca (2017), “Fifty Shades of Consent?”, In Feminist Media Studies, 17.1, 93-107.

VITOUX, Pierre (2007), "The Mode of Romance Revisited", In Texas Studies in Literature and Language, 49.4, 387-410. 